\title{
ANTWOORD AAN GROENEVELD
}

\section{door Prof. Drs. L. van Kampen}

Een criticus dient zich in te leven in de gedachtengang van de schrijver. Dit moet in het onderhavige geval niet zo moeilijk zijn, omdat enerzijds criticus een terzake deskundige is, en anderzijds, naar hij althans zelf constateert, het artikel met logica is geschreven. Vervolgens behoort hij te onderzoeken of de logica inderdaad aanwezig is, of de uitkomsten van de redeneringen aanvaardbaar zijn, geheel dan wel met beperkingen, en zo niet waar dan de fout schuilt. Deze zou dan gevonden kunnen worden in een onjuiste toepassing van de logica, dan wel in een onjuistheid in de grondslagen waarvan de redenering is uitgegaan.

De critiek van Groeneveld doorlezende is het mij niet mogelijk iets van deze taakstelling terug te vinden. Men krijgt de indruk dat hij, zich op het eerste gezicht niet met de conclusies kunnende verenigen, niets anders doet dan trachten deze aan de kaak te stellen.

Het gevolg van de redeneerwijze van Groeneveld is dat ik mij niet alleen genoodzaakt voel om mij hier en daar tegen zijn aanvallen te verdedigen, doch dat ik op mijn beurt als zijn criticus dien op te treden.

Ik moet beginnen met een uitlating van Groeneveld in zijn eerste alinea te bespreken. Hij zegt dat de resultaten van mijn redeneringen veelal tegengesteld zijn aan min of meer algemeen gehuldigde opvattingen. Ik zou hier een kanttekening willen maken. Groeneveld had hier beter kunnen schrijven dat de resultaten van mijn redeneringen afwijken van bestaande opvattingen. Afwijkingen behoeven evenwel niet altijd tegenstellingen te zijn. Ik noem als andere mogelijkheden: aanvullingen op de bestaande gedachtengang, nieuwe gedachten met noodgedwongen nieuwe conclusies. Het kan zijn dat de conclusie meer genuanceerd is; het kan zijn dat zij in het verlengde ligt van de bestaande opvattingen. Het kan ook zijn, en dat is zelfs voorgekomen, dat na enkele jaren een aanvankelijk afwijkende conclusie later door collega's met de hunne werd geintegreerd.

In mijn publikatie had ik betoogd dat er in de bedrijfseconomie een wezenlijk verschil is tussen verschijnselen als kosten, organisatie e.a. en het verschijnsel balans. De eerste zijn a.h.w. natuurverschijnselen, die zich aan de onderneming opdringen terwijl de balans te beschouwen is als een kunstproduct, dat men dient op te maken niet om wille van de onderneming zelf, maar omwille van contacten met de buitenwereld, om te voldoen aan verplichtingen die men op zich genomen heeft. Dit geeft aan de balans een afzonderlijke plaats.

De functie van de balans voorzover naar buiten gericht dient om de rechten van de winstgerechtigden vast te stellen waaruit de naar binnen gerichte functie direct voortvloeit en wel te zorgen dat door de winstuitkeringen het vermogen niet wordt aangetast. De balans dient ter bescherming, bewaking, van het ondernemingsvermogen.

Daarnaast heeft de balans nog een functie naar buiten naast die van het vaststellen van de uitkeringsverplichtingen en die afzonderlijk hiervan dient 
te worden bezien, n.l. het verschaffen van informatie; informatie welke door de buitenwereld wordt gewenst en informatie welke de onderneming in haar eigen belang wenst te verstrekken.

Tegen deze uiteenzetting worden door Groeneveld bedenkingen geuit. Hij ontkent dat er verschil is tussen verschijnselen als kosten en balans. Dividenduitkering is nodig terwille van de continulteit van de onderneming en dus zal er terwille van die continuiteit ook een balans dienen te worden opgemaakt. Er dient dividend te worden uitgekeerd. Hij zegt: ,En dit zou dan niet uit de onderneming zelf voortspruiten? Kostprijs zou wel zo'n aangelegenheid zijn, maar de op basis van die kostprijs gevoerde prijs- en winstpolitiek zou dit niet zijn?

Ik moge terzijde opmerken dat het woord ,,winstpolitiek" in de mond van een aanhanger van de vervangingswaardeleer merkwaardig klinkt. Ik wil aannemen dat dit een slordigheidje is en dat ,uitdelingspolitiek" wordt bedoeld.

Wat de hoofdzaak van de onjuistheid in de geciteerde zin betreft: het is niet mogelijk wetenschappelijke redeneringen met politieke argumenten te bestrijden. Prijspolitiek en uitdelingspolitiek zijn aangelegenheden waaraan elke onderneming haar aandacht dient te schenken, doch in een wetenschappelijk betoog dat als uitgangspunt heeft de objectiviteit van de winstbepaling, behoren deze begrippen niet te worden gebruikt. Uitdelingspolitiek kan nimmer een argument zijn om de plaats van de balans in een wetenschappelijk stelsel aan te tonen of te bestrijden. Immers voordat van een uitdeling of het voeren van uitdelingspolitiek sprake kan zijn, dient vastgesteld te worden in hoeverre het beklemd vermogen in stand is gebleven. De vraag in hoeverre men een eventueel overschot wil uitkeren kan dan aan het uitdelingsbeleid worden overgelaten. Hieruit volgt dat het voeren van een uitkeringsbeleid aan de functie van de balans niets wijzigt.

Groeneveld betoogt dat het noodzakelijk is dat men dividend uitkeert om de continuiteit van de onderneming te waarborgen, resp. expansie mogelijk te maken, daar men hiervoor de vermogensmarkt nodig heeft. Deze stelling zou ik willen bestrijden en wel omdat zij onjuist is. Het feit dat vele ondernemingen met hun dividendpolitiek de vermogensmarkt trachten open te houden omdat zij die voor hun voortbestaan of expansie nodig hebben, bewijst nog niet dat zulks in alle gevallen zo is. Wanneer de winstcapaciteit van de onderneming groot genoeg is voor de financiering van de expansie uit de reserveringen heeft men de vermogensmarkt niet nodig en behoeft men met zijn dividendpolitiek met die markt geen rekening te houden. Slechts onvoldoende winsten maken een ,,dividendpolitiek" noodzakelijk en wel een die op emissies is gericht.

Groeneveld heeft er dus bezwaar tegen de balans in een andere categorie in te delen als de kosten: ze zouden beide de continuiteit dienen.

Dat dit direct of indirect bij beide het geval is mag evenwel niet verhinderen op de verschillen die er zijn te wijzen. Het is zelfs voorwaarde voor wetenschappelijke vooruitgang om de verschillen tussen verschijnselen aan te tonen. Wanneer men verschillen die van belang zijn niet wenst te zien houdt men de ontwikkeling van de wetenschap tegen. Wat men eventueel zou kunnen betogen is dat de aangeduide verschillen geen echte verschillen zouden 
zijn, doch dat deze op muggenzifterij berusten. Doch dan dient men de op basis van die verschillen beredeneerde conclusies aan te vechten en aan te tonen dat ze geen waarde hebben.

Groeneveld heeft bezwaar tegen mijn stelling dat winstvaststelling een inleiding zou zijn tot liquidatie van een deel van het ondernemingsvermogen.

Ik maak er op-opmerkzaam dat Groeneveld tweemaal deze zin verkeerd citeert als volgt: ,Winstuitkering is een inleiding tot liquidatie van het ondernemingsvermogen". Met name het weglaten van de woorden ,een deel van” maakt de zin kennelijk onjuist.

Groeneveld maakt van de gelegenheid gebruik uitvoerig op allerlei punten van dividendpolitiek in te gaan. Hij zegt: de onderneming leeft bij de gratie van de winstuitkering. Eerder heb ik betoogd dat dit niet in het algemeen kan worden gesteld. Hoe dit ook zij, het doet aan mijn betoog niets af. Wanneer men een visje uitgooit om een kabeljauw te vangen, moet men toch ook beginnen met iets op te offeren. De dividenduitkering kan men als dit offer zien, en het is duidelijk dat men na de uitkering minder kasmiddelen heeft dan daarvoor, en dat het vermogen is verminderd. Dit wordt in vele gevallen zelfs wel eens pijnlijk ervaren, indien men b.v. het geld liever voor andere zaken had willen gebruiken. Ik heb slechts dit feit van het offer willen constateren en dit in mijn terminologie aangeduid als ,liquidatie van een deel van het ondernemingsvermogen". Ik vermag niet in te zien dat hier bezwaren tegen kunnen bestaan en de critiek van Groeneveld kan dan ook tegen mijn stelling niets uitrichten.

Als onderdeel van zijn critiek vestigt Groeneveld de aandacht op de kwartaalberichten die een functie vervullen in het contact tussen de onderneming met de buitenwereld. Het is mij niet begrijpelijk waarom hij dit element, hetwelk door niemand zal worden ontkend, noemt. $\mathrm{Zij}$ doet niet in het minste iets af aan de vermogensbewakende functie van de jaarbalans.

Groeneveld noemt het een sprookje dat toepassing van het systeem van de vervangingswaardeleer in de boekhouding tot veel werk aanleiding geeft. Hij stelt dat de onderneming de nieuwe waarden toch moet kennen op straffe van ondergang. Met deze laatste uitlating kan men het eens zijn, doch het is niet nodig dat daartoe de boekhouding op basis van de vervangingswaarde wordt gevoerd. Voor het kennen van de vervangingswaarde bestaan betere, snellere en minder kostbare middelen.

Groeneveld stelt in tegenspraak met mijn betoog dat de vervangingswaarde wel degelijk met het effect van de wederinkoopprijzen rekening houdt. Dit moet ik tegenspreken. Er zijn wel schrijvers, die proberen door invoering van bepaalde technieken de fouten in de gedachtengang van de vervangingswaardeleer te corrigeren. Doch deze technieken zijn dan altijd ontleend aan hetzij het vervangingskoopstelsel, hetzij aan de techniek van de ijzeren voorraad. En zodra men dit doet kan men beter de kortste weg nemen en deze technieken direct toepassen.

Groeneveld ontkent het nut van mijn stelling dat de balans de aandacht behoort te richten op dat deel van het vermogen dat behouden blijft in plaats van op het deel wat wordt uitgekeerd. Hij vraagt zich af of het ene niet het spiegelbeeld is van het andere. Als de term ,,spiegelbeeld" juist zou zijn, zou 
dit inderdaad wel iets aan de waarde van mijn redenering kunnen ontnemen, omdat men het bestaande begrip slechts van een min-teken zou behoeven te voorzien on het spiegelbeeld te verkrijgen. Doch het gaat hier niet om een spiegclbeeld, doch om een complement. Dit complement was tot nu toe niet gedefinieerd omdat het buiten de belangstelling had gestaan.

Overigens schuilt opnieuw een slordigheid in het door Groeneveld bestreden citaat. $1 \mathrm{k}$ had niet geschreven dat de balans de aandacht behoort te richten enz. doch had bedoeld dat de wetenschapsbeoefenaar dit zou dienen te doen. Opzichzelf is dit niet van belang, tenzij dan dat het opnieuw een bewijs is hoe slordig criticus in het algemeen is tewerk gegaan.

In het tweede deel van zijn artikel komt Groeneveld in wezen nog eens op de kwestie terug. Hij vraagt zich af of het door mij ingevoerde begrip „,beklemd vermogen" geen nauwe relatie heeft tot het vermogen dat volgens Van der Schroeff onder de klem van de vervangingsverplichting ligt. Ook hier is weer verkeerd geciteerd. De vervangingswaardeleer spreekt n.l. niet over ,,vermogen onder de klem enz." doch over ,aanwas onder de klem". De relatie tussen mijn begrip en dat van de vervangingswaardeleer ligt, afgezien van ,,schoonheidsgebreken", aldus dat mijn begrip beklemd vermogen gelijk is aan het oorspronkelijk nominaal vermogen vermeerderd met de ,,aanwas onder de klem" (zou men kortheidshalve mogen zeggen: beklemde aanwas?).

Groeneveld maakt vervolgens bezwaar tegen het feit dat ik in het beginvermogen een normatief element zie om de winst aan te meten. Ik moge erop wijzen dat zulks in meerdere balanssystemen het geval is. Bij het Niederstwertprinzip is het nominale vermogen op de beginbalans de norm voor de bepaling van de winst. Bij het ijzerenvoorraadsysteem is de voorraad op de beginbalans het normatieve clement. In mijn systeem is het beginvermogen eveneens een normatief element doch dan niet gezien als nominaal vermogen doch als reëel vermogen. Dat Groeneveld bezwaar tegen de gedachtengang maakt is onbegrijpelijk tenzij ingegeven door het feit dat de vervangingswaardeleer de beginbalans als normatief element overboord heeft gegooid. Maar dit feit alleen is toch niet voldoende om een andere theorie te torpederen.

Groeneveld maakt over dit punt nog een opmerking en wel over het begrip ,,reëel vermogen”, dat ik in dit verband heb gebruikt. Hij vermoed dat ik met dit begrip mijn eigen gedachtengang verzaak en dat ik hierbij denk aan het aandeelhoudersstandpunt. Dit is mijn bedoeling evenwel niet. Wanneer ik spreek van vermogen, reëel vermogen, beklemd vermogen enz., dan is dit uitsluitend vanuit het gezichtspunt van de onderneming en niet vanuit dat van de aandeelhouders.

In deel drie van zijn betoog neemt Groeneveld het mij kwalijk dat ik niet gewezen heb op het onderscheid tussen de Organische Bilanz van Schmidt en de theorie der vervangingswaarde. Het is wel merkwaardig dat Groeneveld, die zich herhaaldelijk een tegenstander van het maken van onderscheidingen toont, hier de schrijver het verwijt van een niet aangeduid onderscheid maakt. Welnu: ik heb geen anleiding gevonden om het onderscheid te signaleren, en wel omdat het voor mijn betoog van geen belang is en omdat ook in 
absolute zin de verschillen gering zijn. Het zou tijdverspilling geweest zijn op het onderscheid in te gaan.

In deel vier makk Groeneveld weer eens bezwaar tegen een door mij gemaakt onderscheid, en wel dat tussen de beschermende en de informatieve functie van de balans. Het is gemakkelijk dit bezwaar te weerleggen. Er bestaan, zoals ik in mijn publicatie heb uiteengezet, balansen die wel aan de beschermende functie voldoen, doch niet aan de informatieve. Wanneer men dit verschijnsel constateert is daarmede het nut van het maken van het onderscheid aangetoond.

Groeneveld stelt dat ik via een aantal kunstgrepen tot een niet onaardige toepassing van de vervangingswaardeleer gekomen zou zijn. Het gaat hier om het opstellen van juiste balansen, dan wel het corrigeren van onjuiste, buiten de theorie van de vervangingswaarde om. Groeneveld vindt dit blijkbaar zo aardig dat hij een drietal niet met name genoemde collega's ten tonele voert, met wie ik de eer van de prioriteit blijkbaar moet delen. Hun door Groeneveld weergegeven redenering is, afgezien van verschillen in woordkeus, nauwkeurig gelijk aan de mijne.

Ik hoop dat ik nog eens de namen van de drie onbekenden mag vernemen, want het is altijd prettig om met gelijkgestemde zielen van gedachten te wisselen.

Doch, zegt Groeneveld, de gedachtengang heeft bezwaren, want door een rekentruc dreigt het gevaar van uitholling van de vervangingswaardeleer. Dit bezwaar is dus tegen ons alle vier gericht. Ik zou hierop willen antwoorden dat een bezwaar ten opzichte van de vervangingswaardeleer geen enkele betekenis kan hebben wanneer het gaat om een andere theorie, en dus niet in staat is mijn (ons) betoog te treffen.

Ik maak van de gelegenheid gebruik zeer in het kort de essentie van mijn publikatie weer te geven. Ik kan mij n.l. voorstellen dat in het strijdgewoel de lezer het spoor bijster is gaan raken.

Ik heb betoogd dat de bedrijfseconomie, die alle verschijnselen beziet van het standpunt van de onderneming uit en wel in het bijzonder vanuit het gezichtspunt van de continuiteit, consequent dient te zijn en ook de balans vanuit dit gezichtspunt dient te benaderen. En dan wordt de blik vanzelf getrokken naar dat deel van het ondernemingsvermogen, ten aanzien waarvan de balans een functie heeft, n.l. dat deel hetwelk ook na eventuele winstuitkering als blijvend bestanddeel van het ondernemingsvermogen gehandhaafd dient te blijven. De eerste functie van de balans is dit vermogen te bewaken en deze bewakende functie, de functie in de continuiteit, valt dan de benaming ,bedrijfseconomische functie" toe. De eerste functie van de balans is dit vermogen te beschermen, en ervoor te waken, dat er niet een gedeelte van wordt uitgekeerd. Slechts het overschot, de winst kan worden uitgekeerd. Van winst is eerst sprake indien het reële eindvermogen het reële beginvermogen overtreft. Het Niederstwertprinzip beschermt slechts het nominale vermogen, en behoort daarom tot de nominalistische theorieën. De ijzerenvoorraad techniek beschermt een stuk actief, terwijl de vervangingswaardeleer zich concentreert op de vervanging van afgestaan actief. Beide theorieën dienen daarom tot de substantialistische theorieën te worden gerekend. 
Het vermogen, hetwelk in mijn gedachtengang dient te worden bewaakt heb ik de benaming ,beklemd vermogen" gegeven. De relatie van het beklemd vermogen tot de winst is er een van complementariteit. Zij kan worden uitgedrukt in de formule: totaal vermogen is gelijk aan beklemd vermogen plus winst.

Door elk van de beide laatstgenoemde factoren te definiëren ontstaat een toetsingsmogelijkheid op de onderliggende theorieën en op het gebruik ervan, die niet hoog genoeg kan worden gewaardeerd.

Naast de vermogensbeschermende functie heeft de balans ook een informatieve functie. Is de eerstgenoemde naar binnen gericht, de informatieve functie is die ten opzichte van de buitenstaanders, ten opzichte van diegenen, die niet met de leiding zijn belast, doch die wel op enigerlei wijze belang bij of belangstelling voor de onderneming hebben. Onderzocht werd of en in hoeverre bij de verschillende balanstheorieën en technieken de beide functies worden vervuld. Hierbij bleek o.m. dat het mogelijk is dat een balans wel voldoet aan de ene functie, doch niet aan de andere. Om beide te kunnen verzoenen dient men de begrippen netto-waardering en bruto-waardering te hanteren. Tenslotte werd nagegaan hoe een balans die onjuist is opgemaakt, d.w.z. aan tenminste één van de functies niet voldoet, kan worden gecorrigeerd op zodanige wijze dat beide functies worden bevredigd. 